\title{
Are daily sedation stops safe in a medical ICU?
}

\author{
AS Debue*, J Charpentier, M Arnaout, J Busson, C Boulila, S Cabon, J Dhumeaux, N Ericher, S Lefort, P Lucas, \\ A Marincamp, M Reffiena, A Cariou, JP Mira, JD Chiche, Groupe de Travail sur la Ventilation
}

From ESICM LIVES 2015

Berlin, Germany. 3-7 October 2015

\section{Introduction}

Despite evidence that daily sedation stops (DSS) by nurses reduce duration of mechanical ventilation (MV), DSS are not part of routine practice in most ICUs. Reasons for slow adoption include scepticism over efficacy, logistical burden in initiating changes, and fear of adverse events during sedation stops. Whether sedation stops are associated with significant adverse events is unknown.

\section{Objectives}

This study aims to evaluate adverse events occurring during 2-hour DSS in a medical ICU.

\section{Methods}

We have retrospectively reviewed charts of all pts mechanically ventilated in the 24-bed MICU of Cochin University Hospital. In the absence of contra-indication, all pts underwent a 2-hour DSS as part of our combined sedation \& weaning protocols. During and at the end of DSS, adverse events, need for bolus or infusion of sedative agents, and RASS scores were prospectively recorded in a clinical information management system (Clinisoft $^{\circledR}$, GE Healthcare). Data are reported as median and interquartile ranges. A P $<0.05$ was considered significant for all statistical tests performed.

\section{Results}

Between 03/08 and 04/15, 9799 pts ( 5760 M/ 4039 F, 62 [46-76] y.o., SAPS2 43 [29-60], SOFA 5 [2-8]) underwent 12,474 DSS. No significant adverse event occurred in 12,217 (97.9\%) of the DSS. Adverse events included patient-ventilator asynchrony ( $\mathrm{n}=159$ DSS), O2 desaturation $(\mathrm{n}=159$ DSS), accidental catheter removal $(\mathrm{n}=22)$, fall $(n=9)$. However, mild to moderate agitation occurred during 2,483 DSS (19.9\%) and led to prematurely resume

Cochin Port Royal, MICU, Paris Cedex 14, France
Table 1. Sedatives administered during DSS

\begin{tabular}{ccccc}
\hline & BZD & Opiates & Propofol & Others \\
\hline Infusion & $984(57.6 \%)$ & $575(33.7 \%)$ & $127(7.5 \%)$ & $21(1.2 \%)$ \\
\hline Bolus & $182(23.4 \%)$ & $240(30.9 \%)$ & $26(3.3 \%)$ & $241(31 \%)$ \\
\hline
\end{tabular}

continuous sedation ( $\mathrm{n}=1707,13.7 \%)$ or to administer boluses of sedative agents $(n=776,6.2 \%)$.

\section{Conclusions}

Overall, daily sedation stops are safe and associated with few adverse events in a setting with nurse-driven monitoring of neurological status. Administration of sedative agents may occasionally be needed to control mild to moderate agitation that may lead to adverse events.

Published: 1 October 2015

doi:10.1186/2197-425X-3-S1-A26

Cite this article as: Debue et al: Are daily sedation stops safe in a medical ICU? Intensive Care Medicine Experimental 2015 3(Suppl 1):A26.

Submit your manuscript to a SpringerOpen ${ }^{\odot}$ journal and benefit from:

- Convenient online submission

- Rigorous peer review

- Immediate publication on acceptance

- Open access: articles freely available online

- High visibility within the field

- Retaining the copyright to your article

Submit your next manuscript at $\gg$ springeropen.com (c) 2015 Debue et al.; This is an Open Access article distributed under the terms of the Creative Commons Attribution License (http:// creativecommons.org/licenses/by/4.0), which permits unrestricted use, distribution, and reproduction in any medium, provided the original work is properly cited. 